\title{
The Politics of Space and Language: Demythologizing the Black Community in Harper's Iola Leroy
}

\author{
Majid Salem Mgamis ${ }^{1}$ \\ ${ }^{1}$ English Department, Tafila Technical University, Jordan \\ Correspondence: Majid Salem Mgamis, English Department, Tafila Technical University, Jordan. E-mail: \\ esotericities@yahoo.co.uk
}

$\begin{aligned} & \text { Received: October 26, } 2014 \\ & \text { Accepted: January 4, } 2015 \quad \text { Online Published: February 25, } 2015 \\ & \text { doi:10.5539/ells.v5n1p78 }\end{aligned} \quad$ URL: http://dx.doi.org/10.5539/ells.v5n1p78

\begin{abstract}
This paper reads Harper's Lola Leroy from a different perspective. As a noel that is concerned with black identit, it subverts the degrading stereotypes of the black community. In the novel, Harpers rejects the socially-constructed stereotypes through the characters she employs. These stereotypes lead to the marginalisation and exclusion of the black in both the Norh and the South. In turn, Harper creates a new image for the black people, which comes through the skillful planning of the the evenets in the novel and the deliberate employment of language.
\end{abstract}

Keywords: Lola Leroy, African American Literature

Contemporary scholarships on Iola Leroy tend to focus chiefly on the character of Iola. Hence, the thematic significance of the book has been largely defined in terms of black women issues, which essentially underestimates the immense political agenda of the novel. It is true that Harper offers a splendid view of the racial injustice the black community faced in the 19th century, and depicts characters who fight for their freedom on both the gender and race arenas, however, Iola Leroy is more than a record of the black American struggle before and after emancipation. The novel encompasses considerable political issues that Harper raised in terms of the black experience in the reconstruction era.

One of the major issues which the novel highlights is the question of the black identity. In more particular terms, the novel expounds Harper's deconstruction of the degrading stereotypes of the black community. The author denounces these culturally-constructed stereotypes through the image she creates for her characters in both the North and the South, and thus manages to break rigid and oppressive stereotypes associated with them. Harper employed her literary acumen to refute the stereotypes of African American men and women, which lead to their marginalization and exclusion. The new image Harper creates for the black individual and community is orchestrated through the deliberate structuring of the events based on the North and the South, and through the thematic employment of language, namely the oscillation between the standard and the dialect.

From the outset, Harper highlights the salves intelligence and their ability to adapt to the reality the live in. The slaves' faked indifference to the Civil War is an example. Their indifference to the issue of the war transforms into a survival tactic to avoid any jeopardy resulting from any personal attitude on their side. Even more, the religious gatherings under slavery carry more than the mere religious meaning. They become an outlet to share "prayers and tears, and lay plans for escaping to the Union army. Outwitting the vigilance of the patrollers and home guards, (slaves) established these meetings miles apart, extending into several States" (Harper, p. 13). This is a clear message that the real nature of the slaves is not as it is publicly recognized..

Such methods of survival did not stop after emancipation. In fact, one of the major concerns in the novel is that the black Americans after emancipation are not much better off than before it. However, in this stage the survival mechanism became more open and focusing on exhibiting racial solidarity. One of these tactics is represented in rejecting passing. By emphasizing their loyalty to the race, the newly-emancipated population confirmed their struggle for self-affirmation.

The idea of rejecting passing becomes more illuminating when demonstrated by those who have a wider opportunity to pass as white by virtue of being light-skinned; most important of whom is the protagonist. Iola, a mixed-race woman, rejects the idea of passing and embraces her black identity. More stunningly, she rejects the proposal of Dr. Gresham; not out of fear of him discovering her identity, but out of worry that their union would 
not pave the way for her to achieve self actualization. She affirms that she "could not accept his hand and hide from him the secret of (her) birth" (Harper, p. 111). When she ultimately reveals her true race to him, she continues asserting: "I have too much self-respect to enter your house under a veil of concealment" (p. 117). Iola's loyalty to her race exceeds her personal desires as she expresses her commitment to her racial heritage: "I intend, when this conflict is over, to cast my lot with the freed people as a helper, teacher, and friend. I have passed through a fiery ordeal, but this ministry of suffering will not be in vain" (p. 114).

Accordingly, it is not surprising that Iola accepts Latimer's proposal for issues that have to do with her dedication to her race rather than her emotions. Latimer is a man of equal racial and intellectual status; these are personal traits that will help her enhance her position regarding her race issue. After all, Latimer's "words were more than a tender strain wooing her to love and happiness, they were a clarion call to a life of high and holy worth" (p. 271). Iola's marriage to Latimer also subverts the conceived image about the black people on the levels of race and gender. As remarked above, Iola's marriage to Latimer is based on a purely rational motive, rather than a mere emotional feeling. He will boost her efforts dedicated to her race. Second, their relationship details show a great deal of mutual respect that not only dislodges the stereotypes about black women and men, but proves the comparatively debilitating situation of the white institution of marriage.

By and large, the $19^{\text {th }}$ century was a period when women faced the atrocities of the patriarchal hegemonic society. Iola's and Latimer's union proves the opposite. It is a marriage that is based on mutual respect and understanding. Interestingly, it is Iola who almost has the upper hand in terms of being the leader for her fellow slaves' emancipation. Whereas the white man substantiates his macho in exerting his authority, the black man's individuality is exhibited by the extent to which he supports his race issue and be involved in the domestic sphere with the woman on equal footing. Harper seems to be conveying the message that the welfare of the community starts from the healthy domestic relationship. In this sense, Iola Leroy's political agenda encompasses issues related to both race and gender.

That is why one may well argue that Iola's position subverts the socially-designed image of the black Americans; men and women. Iola is endowed with heroic attributes that set her as an example for her fellow black women. She refuses to pass as white, and she does not accept the role of the angel in the house within the institution of marriage as both acts necessitate the concealment of her racial heritage. Instead, she dedicates herself to the welfare of her race, refuses to be entrapped in the private zone and chooses to navigate in the public domain, which was considered the prerogative of man. As Carla Peterson points out, "Iola works to redeem her race, not by remaining by the hearth, but by mediating between private and public spheres within the black community - between home, church, and school" (p. 102). This is a clear manifestation of the political role black women may play in the post-war era.

Another prevalent idea about black females that Harper refutes through Iola has to do with their sexuality. In spite of different attempts by white people to engage in sexuality with her, Iola maintains her chastity. In addition to its significance on the moral side, this also stands as a living testimony on the strength of Iola; a black lady in the face of hegemonic white stream; Harper states that Iola was competent in defending herself against "the highest insults that lawless brutality could inflict upon innocent and defenseless womanhood" (Harper, p. $39)$.

The challenges Iola faces are not restricted to her emancipation project; rather they extend to the work field. The white society, for example, imposed limitations on employing the black in a department store. That is why once her ethnicity is discovered, Iola resigns. It is not that she is unable to stand for her case, but the extreme racial limitations she faces are compelling. In fact, from the beginning, Iola's uncle objects to her working in a department store since the white employer "doesn't expect any colored girl to apply" (Harper, p. 205). This shows that Harper's black characters seem to be fully aware of the limitations imposed upon them by the dominant white power. However, despite their awareness of the racial prejudice imposed on them; Harper's characters do not give up. Instead, they are keen on challenging this racial inequality and thus disproving cultural stereotypes about themselves.

The novel does not challenge the stereotypical image associated with black women only, black men are also depicted in a way that departs from the mainstream belief associated with them. In this particular arena, Harper's novel portrays black male characters who are very far from fitting in the societal degrading stereotypes. To this end, Harper is keen on showing different layers of black males in her text. For instance, there is Robert, who is relatively of more advanced status compared to his slave peers. Uncle Daniel is an example on the less educated and sophisticated black. He does not speak Standard English and is almost illiterate. Other characters who fit in the typical frame of the black man is Tom Anderson, who exhibits substantial dedication to his racial heritage. All 
these and other characters, beautifully gathered in a "carnivalesque" atmosphere, are dexterously portrayed in a way that helps promulgating a new image of the black community; an image that necessarily goes against the dominant notion.

From the outset, Iola Leroy presents the black man's courage and stamina. Tom, Robert and Harry are portrayed as heroic black men who eagerly look for their role in the war. This challenges the prevailing notion about the cowardice of the black men in the South. Although Tom seems to be physically unfit for the war, his death represents a best example on the idea of sacrifice for the sake of the race. Clearly enough, these instances undermine the stereotypical image associated with black men. They also deconstruct the belief that only the white men posses the sense of courage and power. This undermining of the racial stereotypes constitutes one of Harper's major political message in the novel.

Another impressive trait which Harper exhibits in the novel is the black male's dedication to his domestic duty. In the nineteenth-century America, the domestic domain was primarily the duty of the woman, whereas men enjoyed the liberty in the public sphere. Put in this context, the black men's tendency towards domesticity deconstructs the system of white male power and establishes a new view of the black community in general and the black men in particular. Uncle Ben stands as a living testimony on this idea. He is depicted as a man who would sacrifice anything for meeting his obligations towards his mother. Although he is so enthusiastic to participate in the war, he prefers to stay next to his aging mother; "I mean to stick by her as long as there is a piece of her." Uncle Ben's sentimental feeling appears more as he says "I can't go over to the army an' leave her behind, for if I did, an' anything should happen, I would never forgive myself.... I don't want to be free and leave her behind in slavery" (Harper, p. 31).

Black men's dedication is not restricted to the domestic sphere; rather, it extends to the fulfillment of all obligations even on the expense of one's liberty. Uncle Daniel, for example, refrains from joining the Union forces in order to meet his duties for his master. This is clear indications that, for him, the fulfillment of these duties are more paramount than his desire for emancipation. In fact, the motive behind Uncle Daniel's decision is not far from that of Uncle Ben's. His master took him as a surrogate mother, and it was Master Robert who facilitated Daniel's marriage to Katie. Daniel vehemently states that his aspiration for freedom outweigh his domestic duties; "I'se mighty glad you hab a chance for your freedom; but, ez I tole yer, I promised Marse Robert I would stay, an' I mus' be as good as my word" (Harper, p. 28). Through the character of both Ben and Daniel, Harper conveys the message that, for black men, loyalty to family is as important as emancipation. This comes in stark opposition to the socially-designed mould in which black people are viewed.

Most significantly, the new image of black men Harper delineates in the novel is essentially enhanced through the character of Robert Johnson. Robert is the epitome of righteousness and honesty. He has a strong case against hypocrisy. More particularly, he rejects the double standard that characterizes the white culture, and that is why he lambasts white men who "could ride to church on Sundays, and talk so solemn with the minister about heaven and good things, then come home and light down on the servants like a thousand of bricks" (Harper, pp. 47-48). Robert refuses to pass as white and chooses to embrace his identity. When he is prompted by other to pass in order to improve his career, he declares his rejection of the materialistic way of thinking stating that "Were I to try it, I would feel like a cat in a strange garret" (p. 43). He considers passing as a way of betraying his race as he addresses Harry, "I think it would be treason not only to the race, but to humanity, to have you ignoring your kindred and masquerading as a white man" (p. 43). Just like Ben and Daniel, for Robert, personal ambition is subsidiary to dedication to issues of others.

Again, just like other slaves, Robert exhibits a great altruism and dedication for domestic obligations. Harper shows that Robert's main concern was to "bind anew the ties which slavery had broken and gather together the remnants of his scattered family" (Harper, p. 148). That is why he works hard to be reunited with his mother after 30 years of separation. When he ultimately finds her at church he declares his concerns as primarily maintaining her comfort addressing her "My dear mother ... now that I have found you, I mean to hold you fast just as long as you live.... I am going to take you home to live with me, and to be as happy as the days are long" (p. 183). Harper shows that Robert was up to his promise as he "had given his mother the pleasantest room in the house, and in the evening the family would gather around her, tell her the news of the day, read to her from the Bible, join with her in thanksgiving for mercies received and in prayer for protection through the night" (p. 267).

Moreover, from the outset, Robert functions as the mediator between the black and the white, especially in the time of war. He is privy to the news about the war from the newspapers by virtue of his education. He later becomes a member in the Union army, and then an officer of the black regiment. Once again, here he is playing the role of the 
link between the white and the black. Robert is also marked for his use of Standard English, as opposed to the majority of the slaves who use dialect.

It is really significant that once Robert masters the standard dialect, his officers express their biased view saying "you do not look like them, you do not talk like the" (p. 44). This is a deliberate hint on how language reflects social standing; a realistic proof that "voice marks class affiliation" (Christmann, p. 5). Still, although Robert's relatively uplifted situation entitles him to pass, he refused to do so. Robert, Iola and Latimer's rejection to pass as white solidifies the moral side of the black people despite the great challenges they face. After the war, Robert heads North with the Leroy family and embarks on his business. In the North, Robert faces the great white prejudice; still he manages to achieve success.

The splendid picture Harper draws for the black men and women is more crystallized in their interpersonal relationship; namely in marriage. To put things in context, one should take into consideration that, before emancipation, the black did not have the right to marry. It is the Emancipation Proclamation that gave the African American the right to wed. As Claudia Tate points out, since African Americans were not given the right to wed, marriage in the reconstruction era became as a manifestation of black Americans' civil rights. She states that marriage became "the very sign of social progress for black Americans; it provides the medium for expressing a people's affirmation of their civil liberty and for measuring their propensity for civilization" ( $p$. 117).

In the case of Iola, it is very clear that her decisions regarding marriage are strongly connected to her affirmation of her black identity. She rejects Dr. Gresham's proposal since their marriage would entail eradicating her racial identity. She accepts Dr. Latimer's as this marriage would enhance her self-realization as a black woman and help her dedicate her efforts to the black community. It is these hopes and purposes which they both have in mind as Harper describes them: "Kindred hopes and tastes had knit their hearts; grand and noble purposes were lighting up their lives; and they esteemed it a blessed privilege to stand on the threshold of a new era and labor for those who had passed from the old oligarchy of slavery into the new commonwealth of freedom" (Harper, p. 271). Iola's marriage carries significant implications on the levels of both race and gender. Iola's union with Dr. Latimer does not confine her to the domestic sphere; rather it gives her more potential to contribute to the public sphere. This sphere is the black community which has suffered under the debilitating effect of slavery.

For black men, matrimony holds different, though not less significant, meaning. Interestingly enough, whereas marriage for black women announces their entrance to the outer space, the marital life for black men enhances their domestic orientations. Again, Robert is the best embodiment of the black male's investment in home and family though he never gets married and evades any attempts to even discuss the topic. He responds to Aunt Linda's encouragement for marriage either by smiling or changing the topic. One should note that Robert's resentment from marriage does not contradict Harper's concern with black men's commitment to home and family. Through the case of Robert, Harper conveys the message that familial obligations can also be realized outside wedlock.

In fact, Robert's seclusion as well as his general silence over the race issue at the end represents one of the novel's main thematic concerns regarding the status of the black after the war. Through Robert, Harper conveys the message that black Americans who were not completely attached to their community did not fully experience the taste of freedom and did not contribute a lot to their race. It is true that Robert was a very active participant in his race issue during the war and played a vital role in reuniting his family as well; however, after the war, Robert's patriotism almost fades away. Harper's concern here is with the solidarity of the race. Robert, having chosen to retreat, is of no much use to the race.

This is actually one of the fundamental political issues that critics neglected in their approach to the novel. One should not read the black experience as a collective framework. Rather, several demographical and geographical factors may play a critical role in forming the identity of the black individual, thus reflecting on his experience in the struggle for emancipation. In this sense, Robert's silence may also be a representation of the author's political agenda regarding embracing the white hegemonic dictates. Since matrimony for the black people comes within the logic of the white society, Robert's reticence against marriage may be well interpreted as a repudiation of this logic. In this way, Harper is keen on emphasizing that the rejection of the mainstream ideology in the reconstruction era should not be less than it is in the pre-war era.

In this respect, Aunt Linda constant rejection of literacy is an impeded repudiation of the white model of emancipation designed for the black. For Linda, learning is inferior to gaining basic civil liberties. She screams: "I'se bin scratchin' too hard to get a libin' to put my head down to de book" (Harper, p. 156). Interestingly, despite her abhorrence of reading, Linda is quite intelligent. Her illiteracy is meant to be as an intended desire for being 
uneducated. Harper clearly illustrates Linda's temperament as she states that "Aunt Linda was kind and obliging, but there was one place where she drew the line, and that was at learning to read" (p. 276).

Linda's rejection of literacy articulates Harper's critique of assimilating the ideology of the dominant stream. Linda's life experience becomes as an alternative source of knowledge. Her reluctance to learning is part of a rejection of the dominant ideology that may diminish the racial heritage. Although she praises the white men who participated in the war for the black side, she does not assimilate the frame they set for emancipation and seeks her own version of freedom. For example, she appreciates the fact that prayers are no longer held in secret; however, she regrets the fact these religious meetings are not as sincere as they used to be in the pre-war era; she says "(I)t don't seem as ef de people had de same good ligion we had den. Pears like folks is took up wid makin money an politics" (Harper, p. 162).

Linda's position comments on the prejudice African Americans face even after emancipation. For example, even Iola and Robert, who have self-respecting life in the North, face manifestations of racial inequality. Iola faced this intolerance in her search for employment, from both employees and employers, and suffered a great deal of prejudice in the job field; Robert also suffered a lot in his attempt to find a house as white landlords refused to rent him a place. Once again, Harper is showing that the emancipation desired is still to come. The post-war era is just a first step toward attaining the real taste of freedom. In brief, Harper is interested in presenting the real situation of the black people in the reconstruction era, and arguing that such undesirable realties should be faced by rejecting the white logic of discrimination and prejudice.

Speaking of the North, it is imperative to note Harper's dexterous employment of space and geographical territories for the purpose of promulgating her political agenda. Although the black people attain some sort of emancipation in the North, they return to the South as they aspire for more racial equality. The desire to be away from the white community is a clear indication of the degree of discomfort experienced there, and it also points out to the idea of seclusion as a mechanism for survival. For Harper, social progress does not necessarily mean being assimilated in the mainstream. Interestingly enough, although most of the story is told in retrospect, the narrations shifts to the present once the family embarks on its journey for more freedom. Again, this is a stylistic message on the part of Harper indicating that more is yet to come as far as racial happiness is concerned.

In utilizing space for thematic significance, Harper manages to insinuate her message through the symmetrical structuring of events within the territories of the North and the South. In this respect, there are two major scenes that exemplify Harper's dexterity. The first scene is in Chapter 10 where Iola, Robert and Harriet gather in the church as a symbol of reunification. The second scene is in Chapter 30, in which Iola moves to a new stage where she becomes the advocate for her race.

Harper creates a significant parallelism between these two scenes. The first scene occurs in a rural setting in the South, the second in an urban setting in the North. The meeting in the church primarily gathers black people; the atmosphere is rather melancholic and replete with enthusiasm. On the other hand, the second scene features light-skinned and intelligent individuals with high sophistication and sense of ambition. In contrast to the first scene, which is characterized by concern over the misery of the black community, the second scene exhibits characters who discuss the future of the race. Barbara Christian argument about this scene shows that, "the tone is one of uplifting the race, of rescuing it from its own culture, of molding black women and men superior to white people according to their own Christian mores" (p. 28). More on Harper's deliberate structuring the event, it is important to note that during the early secret religious meetings some of the slaves were reluctant to achieve individual progress. On the other hand, the later meeting shows individual who have high spirit for uplift and discuss the future of the race "on the broad basis of equal justice and universal freedom" (Harper, p. 226).

Despite these differences, the two scenes share a marked stress on speech in comparison to the discourse of discussion that dominated the novel. The language that permeates the first scene is primarily the dialect of the African Americans in addition to some elements of the standard. Hence, it can be taken as an example on the Bakhtinain "polyphonic" (dialogic) discourse. Harper combines a multiplicity of voices in a quite democratic atmosphere, where everybody's voice is heard. The standard dialect that characterizes the second scene is a representative of the "monologic" discourse, where there is only one voice to be heard. Shifting between these two divergent discourses, Harper alludes to the diversity of opinions regarding the status of the black. In other words, the "heteroglossic" atmosphere represents the different approaches adopted for handling the black issue.

By granting the black individuals considerable verbal capabilities, Harper answers Spivak's concern by letting "the subaltern speak" (p. 1). In addition, the "carnivalesque" atmosphere that Harper creates substantiates her concern for racial solidarity. The combination of standard and dialect, with both African Americans and the bourgeoisie, speaks to the possibility of a future where all these differences diminish and where the subaltern can 
substantiate their voice and subjectivity. This culture is also accentuated in the camp meeting scenes. The democratic atmosphere is built through the discussion over the Union Army. The discussions involve various voices with different vantage points regarding the topic.

The deliberate use of language for thematic purposes permeates through the novel. The early chapters are almost characterized by the use of dialect, whereas the later chapters show an almost systematic use of the standard. The only characters who maintain their distinctive dialect are the old ones. This is an indication that the black youth are the ones who are going to hold the emancipation torch. In the case of Iola in particular, the reader can trace a great shift in her language as the novel unfolds. In the early chapters, Iola's speech is rather shadowy indicating that "great sorrow had bound her heart in loving compassion to every sufferer" (Harper, pp. 39-40). However, as the novel progresses, Iola's voice gains more power. As mentioned above, in the second scene Iola engages in a discussion over the future of the race in which a sense of "triumph in her voice" appear and her words reflect "a higher service and nobler life" (p. 257). The shift in Iola's discourse is emblematic of the clear uplift in her status as a mulatto.

The same perspective applies to Robert. Introduced at the beginning as a slave who masters both the black dialect and the Standard English, Robert, with the progression of the novel, almost exclusively uses the standard. The message is clear; language is greatly connected to the social status. Once the African Americans are freed from the boundaries of slavery, their language gains a socially-accepted prestige that makes them fit more into the class system of the dominant stream.

Even more on the thematic significance of language, the dichotomy between dialect and standard extends to the black community itself. Tom Anderson's case represents this thematic dichotomy. Tom's distinctive dialect renders him socially inferior even to his fellow black Americans. The different status between him and Robert, for example, appears clearly. Tom joins the army as a servant, whereas Robert takes the officer position. Tom even does not dare confess his love to Iola since he loves her "as a Pagan might worship a distant star and wish to call it his own" (Harper, p. 40). That is part of why Tom is keen on learning the standard. Even Robert describes him as a deceiver since he tries illegitimate ways to gain the sophisticated standard. Ultimately, it is Tom's low-self esteem that makes him indifferent to his impending death.

It is not only Tom who remains using the vernacular black dialect. The Black tongue remains with the older generation, basically in Aunt Linda. So the distinctive African American voice remains in place even after his death. In this respect, Harper is creating a balance in her emancipation trajectory. As the younger generation cope with the dominant ideology and prove the existence of their race by assimilating some aspect of the dominant stream , the elderly still hold the original racial heritage represented in refusing "the socialization of one culture according to the terms of another" (Ernest, p. 511).

Iola and Robert stand in the middle ground between the two extremes represented by the younger generation's assimilation of the white thought and the older generation's rejection of the white dictates. As mentioned above, light skinned and sophisticated, Iola and Robert have the opportunity to pass as white, but they refuse to reject their racial heritage. Still they master the dialect of the mainstream and at the same time they maintain their racial roots. Even Robert sometimes uses his subaltern dialect in his speech quoting Aunt Kizzy and Uncle Jack. This middle position of both characters, as Carla Peterson explains, is intended "to bridge difference between the two races" ( $p$. 107).

Evidently, Harper orchestrates space and language for thematic purposes. In fact, this stylistic method does not appear only in the above-mentioned scenes; rather, it runs through the whole novel. As mentioned above, the early chapters of the novel are established in black dialect, whereas the final chapters contain both dialect and standard during the visit to the South establishing the dialogic/democratic atmosphere. The opening chapters, which are primarily set in a slave milieu, focus on folk voices; uninflected voices dominate the central chapters; and the final chapters feature a mingling of both, as Robert and Iola revisit the South. As the first chapter contain dialect and the later contain standard, Harper brings both versions together at the end, suggesting a blend and a diversified community. Interestingly, although the dialect reappears, the dominance is for the standard. Harper makes old characters use the dialect, retaining the standard for the younger generation. This is a deliberate message signifying hope for future assimilation with the white community by the young African Americans, rather than the old who are fatigued by the oppression they faced.

Harper's structuring of the events based on the North and the South reflects deep understanding of the black issue and vast knowledge and experience in both territories of the country - especially the misery of the salves- which she gained from her personal life. Harper was a Northern woman herself involved in many organizations and societies dedicated for women and African Americans' issues (Harper, p. xxvii). This position gave her the 
opportunity to travel to the South to get knowledge of "every spectrum of Southern society" (Foster \& Harper, p. 19). As Melba Boyd asserts, "Frances Harper lectured and lived with ex-slaves during the Reconstruction period, listening to their stories, learning about their culture and assisting their struggles for the building of a promised land" (p. 149). This heterogeneous experience made Harper well-informed in both the Northern and Southern hemispheres represented in the white hegemonic system and the black debilitating life. This is what made a critic like Henderson's strongly claim that Harper was able to "authoritatively speak to and engage both hegemonic and ambiguously (non)hegemonic discourse" (p. 121).

Equally important, the period in which Harper wrote her novel witnessed a national uprising of the Southern issue. The black were facing a conflict represented in either complete submitting to the White frame of freedom or exerting great efforts to prove their eligibility of the emancipation they achieved. In these respect, there were ventures on the African American side that aimed at upgrading the social level of the Southern slaves especially in the educational field. Within this context, Harper's novel comes to boost the cultural acceptance of the African Americans in the dominant stream by undermining the stereotypical beliefs associated with them.

Accordingly, Iola Leroy is not a text that merely celebrates the post-war proportional freedom of the black as much as a book that stands as a reminder for what is to be done for the real emancipation to take place. As the novel deconstructs cultural stereotypical images of the black, it suggests that the social realities of the black will never truly progress as long as the black community is satisfied with the status quo. In her exploration of the black community in the North and the South, Harper insinuates her political vision about the African Americans men and women, as individuals, couples and groups. The novel debunks the prevailing stereotypes about the black people and offers a viable vision that bespeaks of a better future for the black individuals and community.

Evidently, Harper manages to create a new perspective from which to view the black question more keenly. The book thus can be considered as a real pamphlet on identity politics as far as the black people are concerned. In this respect, the novel may be considered as an answer to Dr. Latimer's request as he prompted Iola to write a "strong" book advocating the case of the black people since "No man can feel the iron which enters another man's soul"" (Harper, p. 263). Harper does write this "strong" book to make others feel this iron in the black people's soul. Hence comes the significance of the novel's subtitle, Shadows Uplifted. Harper uplifts the shadow concealing the truth about the character of the black and their social realities, and it is the reader's task to examine reality as exhibited in the novel.

\section{References}

Bakhtin, M. (1992). The Dialogic Imagination: Four Essays. University of Texas Press.

Boyd, M. J. (1994). Discarded Legacy: Politics and Poetics in the Life of Frances E. W. Harper, 1825-1911. African American Life Series. Detroit: Wayne State UP.

Christian, B. (1980). Black Women Novelists: The Development of a Tradition, 1892-1976. Westport: Greenwood.

Christmann, J. (2000). Raising Voices, Lifting Shadows: Competing Voice-Paradigms in Frances E. W. Harper's Iola Leroy. African American Review, 34, 5-18. http://dx.doi.org/10.2307/2901181

Ernest, J. (1992). From Mysteries to Histories: Cultural Pedagogy in Frances E. W. Harper's Iola Leroy. American Literature, 64(3), 497-518. http://dx.doi.org/10.2307/2927749

Foster, F., \& Harper, F. (1990). A Brighter Coming Day: A Francis Ellen Watkins Harper Reader. New York: Feminist P.

Harper, F. E. W. (1988). Iola Leroy or Shadows Uplifted. 1893. Ed. Frances Smith Foster. New York: Oxford UP.

Henderson, M. G. (1990). Speaking in Tongues: Dialogics, Dialectics, and the Black Woman Writer's Literary Tradition. In H. L. Gates Jr. (Ed.), Reading Black Reading Feminist: A Critical Anthology (pp. 116-142). New York: Meridian.

Peterson, C. L. (1994). Further Liftings of the Veil': Gender, Class, and Labor in Frances E.W. Harper's Iola Leroy. In E. Hedges \& S. F. Fishkin (Eds.), Listening to Silences: New Essays in Feminist Criticism (pp. 97-112). New York: Oxford UP.

Spivak, G. C. (1988). Can the Subaltern Speak? In C. Nelson \& L. Grossberg (Eds.), Marxism and the Interpretation of Culture (pp. 271-313). Urbana, IL: University of Illinois Press.

Tate, C. (1989). Allegories of Black Female Desire; or Rereading Nineteenth-Century Sentimental Narratives of Black Female Authority. In C. A. Wall (Ed.), Changing Our Own Words: Essays on Criticism, Theory, and Writing by Black Women (pp. 98-126). New Brunswick: Rutgers UP. 


\section{Copyrights}

Copyright for this article is retained by the author(s), with first publication rights granted to the journal.

This is an open-access article distributed under the terms and conditions of the Creative Commons Attribution license (http://creativecommons.org/licenses/by/3.0/). 